\title{
The Effect of Corporate Reputation on the Performance of Corporate Organizations in Developing Countries: Evidence from West Africa
}

\author{
Kingsley Nwagu \\ Department of Management, School of Research, Texila American University
}

\begin{abstract}
This study is carried out to understand the effect of corporate reputation on the performance of corporate organizations in developing countries: evidence from West Africa. The population for this study consists of selected listed multinational companies in Nigeria and Ghana. The data was collected using a structured questionnaire and was measured on an interval scale through the research questionnaire. The statistical tool used to analyze the set variables is multiple regression. It involves the collection, collation, analysis, and interpretation of data for this study. It further incorporated ANOVA to show CSR Practices and their impact on the performance of corporate organizations as explained by the independent variables through the coefficient of determination $R^{2}$. This design is useful and most appropriate in measuring the degree of association between two or more variables. It is also helpful in measuring the effect of independent variables on a dependent variable. As predicted, the study proves that corporate social responsibility practice can be integrated into corporations' business strategy for enhanced performance. Rather than just being beneficial to society, corporate social responsibility can be the value-added opportunity for corporations that engages in responsible actions. The research adds to the existing literature on corporate social responsibility practices and their impact on corporate performance.
\end{abstract}

Keywords: Corporate Social Responsibility, Corporate organization, Philanthropy, Performance, Reputation, West Africa.

\section{Introduction}

The subject of Corporate Social Responsibility (CSR) is critical because businesses have before now had well-defined economic and legal responsibilities [1]. Companies adopted the term CSR as a management framework to address the overbearing social and environmental shackles bedeviling society. This term, known as corporate social responsibility, became relevant. CSR encompassed a perceived responsibility in areas such as environmental concerns, community involvement, corporate governance, employee relations, and other social performance dimensions. Although there is no consensus on the meaning of Corporate Social
Responsibility, the term generally refers to a current commitment by business to behave ethically and contribute to economic development while demonstrating respect for people, communities, the environment, and society at large. In a nutshell, CSR ties the concept of global citizenship with environmental stewardship and sustainable development. Much of the research preceding our understanding of CSR has concentrated on business-society relationships and dynamics in the developed economies and on awareness, determinants, practice, and disclosure of CSR in developing countries. More recently, there has been a sprouting interest in understanding the dynamics and peculiarities of CSR in emerging economies, vis-à-vis uncovering the relationships between 
CSR practices and organizational performance, especially in the context of financial variables such as profitability. [1-6].

\section{Statement of the Problem}

A pre-study review by the author, of information bothering on CSR practice in developing countries reveals there are levels of CSR acceptance in developing countries which constitutes a problem to a synchronized method. First, some business leaders perceive CSR as a mere best practice activity to gain endorsements for political purposes or otherwise. Leaders in this category intermittently give out cash donations. The second category view CSR as an imposed external practice exported by mother companies of the western world. The other set of leaders understands their dual responsibility to make money for their organization and interact ethically with the surrounding community. These crops of leaders understand that practicing CSR is complex and requires organizational resources such as expertise, personnel, time, and money.

The challenging question for leaders in this category is: how do we recover the funds invested through CSR? What is the impact of CSR practice on the company's performance? The shortage of research studies that survey the impact of CSR practices on the performance of business organizations in this part of the world constitutes a problem to both business and society. Some business leaders refrain from their responsibility to the community due to doubts and fear that they may encounter losses as there is no clear understanding of how social responsiveness affects their organization's performance. Consequently, there is a need to undertake a study on this note to provide clear perspectives for business leaders. This present study, therefore, is set out to answer the question below.

\section{The Objective of the Study}

The objective of the study is to examine the impact of corporate social responsibility (CSR) practices on the performance of organizations with evidence from West Africa.

The specific objective is to examine the effect of reputation on the performance of corporate organizations in developing countries.

\section{Research Question}

This study intends to gather extensive understanding to answer the following question:

How does reputation influence the performance of the corporate organization in developing countries?

\section{Statement of Hypothesis}

The following hypothesis was formulated for this study in null form is as follows:

$\mathrm{Ho}_{1}$ : A firm's reputation does not significantly affect the performance of corporate organizations in developing countries.

\section{Literature Review}

\section{Conceptual Framework}

Corporate Social Responsibility (CSR) is an exciting subject in developed nations and in developing countries. There is a growing interest in CSR, with an increasing number of articles, books, and chapters written on the topic. The content and breadth of coverage are farreaching. CSR is used as an umbrella term to account for the complex and multi-faceted relationships between business and society and the economic, social, and environmental impacts of business activities on the community. This literature review provides a synopsis of concepts and recent studies related to $\mathrm{CSR}, \mathrm{CP}$, and the chance of a relationship between the two.

\section{Corporate Social Responsibility (CSR)}

CSR has been a subject of study for some time, but no consensus concerning its definition and its constituent dimensions, constructs, and principles [7]. A study conducted a comprehensive review of CSR literature and identified 37 different definitions of CSR in 2008. The result from that study shows there is 
considerable variation in CSR perceptions and meanings [8].

For example, two authorities in the field of CSR offer two contrasting views of the responsibilities of business organizations to society. The first argues against the concept of CSR when stating that the only social responsibility of a company is to increase its profits while staying within the rules of the game [9].

In contrast, the second opinion argues that CSR requires consideration of paramount issues beyond the company's fundamental economic, technical, and legal requirements [10]. These two definitions sit on opposite sides. The first suggests that the responsibility of a business is only to its owners. In contrast, the second contends that the interests of other stakeholders, apart from the shareholders, should also be considered. To further put his idea into perspective, the second proposed that the managers of business organizations have four responsibilities that he outlined in order of priority: economic, legal, ethical, and discretionary. He acknowledges that a business must first make a profit to satisfy its financial responsibilities. To continue in existence, the organization must follow the laws and fulfill its legal obligations. There is evidence that companies that violate the law may experience lower profits and a decline in sales [11]. To this end, the two opinions agree.

The second, however, argues further that businesses have responsibilities beyond economic and legal ones. Ethical and discretionary trusts are social responsibilities that organizations should look to fulfilling. CSR, therefore, includes ethical and discretionary but not financial and legal, which are primary responsibilities for business organizations. The fascinating factor here is that both opinions argue their positions based on the impact of CSR actions on the organization's financial performance. The first says that CSR actions will negatively affect the economic efficiency of the business; on the other hand, the second proposes that lack of commitment to CSR results in increased government regulations which reduce the organization's effectiveness.

\section{Corporate Reputation}

According to past and recent research, it is quite clear that corporate reputation significantly contributes to the long-term competitive advantages of organizations, and that is its strategic success factor. Reputation is not easy to define because it depends on various stakeholders' views, intentions, and expectations of enterprise performance. Stakeholders, especially investors and suppliers, would see enterprise reputation from a different angle than the customers. Although both are directly involved, customers focus on quality and include business partners and suppliers mostly assess financial and overall business performance. In this sense, reputation could be defined from the aspect of creditworthiness when they are synonymous. From the customers' points of view, CSR "positively influences customer satisfaction and loyalty within consumer segments" [12, 13]. All other stakeholders - secondary group (media, syndicate, community, etc.) - will estimate from the overall perception mainly oriented to social and environmental interests. Corporate reputation is defined as "a global perception of the extent to which an organization is held in high esteem or regard" [14]. A professor of Business at Harvard Business School likened corporate reputation as a window to the fundamental character of a company and its leaders and, as such, is relevant to all stakeholders [15].

From the shareholders' points of view, reputation stands for a valuable asset, i.e., "intangible resource which may provide the organization with a basis for sustaining competitive advantage given its valuable and hard-to-imitate characteristics" $\quad\left[\begin{array}{ll}15, & 16\end{array}\right]$. Shareholders very often identify reputation with financial position and possibility to gain a profitable return. This is why the emphasis in 
literature is usually placed on enterprise reputation as a valuable resource and its association with financial performance [17-20]. A good reputation could increase sales or revenue and reduce operating costs; thus, reputation is viewed from the aspect of financial benefits and is directed through reputation financial performance relationship. Besides this relationship, it was found that financial performance affects reputation so we could talk about a "reputational vicious circle" [19]. In that case, motivation to accept social performance as one of the reputation determinants could be related to the outcomes of financial gains. Reputation, in a broader sense, could be defined as “a perceptual representation of a company's past actions and future prospects that describes the firm's overall appeal to all its key constituents when compared to other leading rivals" [21].

In co-operation with others, the same author has constructed a definition of reputation relating to various fields - economics, strategy, marketing, organisation theory, sociology, communication, and accounting. About this construction, the authors suggested that corporate reputation is a "collective construct that describes the aggregate perception of multiple stakeholders about a company's performance" [22]. This confirms the statement that reputation is hard to define precisely because it depends on stakeholders' perceptions. Except for this complexity, it should be taken into consideration that companies differ according to their size, business activity, structure, management and leadership, social performance, etc.

For example, heavy industry is more closely linked with some type of environmental and social issues than newer manufacturing industries or the services sector. For that reason, a study proposed that the distinction between types of business activities and social performance plays an important role in defining the relationship between social performance and corporate reputation [23].

\section{Reputation Dimensions}

As a valuable intangible asset, reputation should mostly be measured by qualitative measures. Nowadays, after so many financial scandals, accounting information and measurement are not very reliable and are insufficient for a holistic approach to corporate performance. More and more researchers and practitioners emphasize non-financial measurement instruments as more reliable means for the overall assessment of corporate performance and its reputation. Reputation, as valuable intangible assets, could not be judged only by financial performance, although some researchers argue that financial performance has a positive influence on reputation, i.e., it was found that financial performance affects reputation [19]. Reputation is a much broader concept and deserves to be estimated by qualitative and quantitative (financial and nonfinancial) indicators.

\section{Theoretical Framework}

\section{Theoretical Views of Corporate Social Responsibility (CSR)}

As earlier posited, CSR's staple idea holds that business and society are not separate but interlocked [24]. Scholars have identified theories to explain CSR. For instance, stakeholder theory explains how CSR is essential, and the contractual and legitimacy theories explain why CSR is critical [25]. CSR includes several theories, and many studies have discussed contractual/agency, stakeholder, and the social contract behind the idea of corporate social responsibility. However, this study is hinged on Legitimacy theory, as elaborated below.

\section{Legitimacy Theory}

Legitimacy theory is the most widely used theory to explain environmental and social disclosures [26]. According to a study, legitimacy theory is preferred chiefly over other theories because it provides disclosing strategies that organisations may utilize to legitimize their 
existence that may be empirically tested [27]. Legitimacy theory is traceable to the concept of organizational legitimacy, which has been described as a condition that exists when an organization's value system is consistent with the value system of the society of which the organization is a part [28]. There is a threat to the organization's legitimacy when a disparity, whether actual or potential, exists between the two value systems.

Legitimacy theory posits that entities repeatedly seek to ensure that they operate within the acceptable norms of their respective societies. In adopting a legitimacy theory perspective, an organization would willfully report on activities if managers perceived that those activities were relevant to the communities in which it operates [29-31]. Because community expectations vary over periods and time, the organization needs to make available information to show that it is also changing. The study indicates that legitimacy is a huge resource on which an organisation depends on survival [28].

Another study provides that, consistent with resource dependence theory, legitimacy theory suggests that whenever managers consider the supply of the resource as critical to organisational survival, they will pursue strategies to ensure the continued supply of that resource. Such strategies may include targeted disclosures or perhaps controlling or collaborating with other parties who, in themselves, are considered to be legitimate [29, 30]. Where managers perceive that the organisation's operations are not commensurate with the society's interest, then pursuant to legitimacy theory, organisations may take strategic action to become legitimate. Because the theory is based on perceptions, for remedial action to have an effect on external parties, it must be accompanied by publicised disclosure. Hence the importance of publicised corporate disclosures, such as those made within annual reports and other publicly released documents [31].

\section{Empirical Review}

They are considering the unethical company and brand perceptions, A study based on three empirical studies out to conceptualise and subsequently operationalise the construct of consumer perceived ethicality (CPE) of a company or brand. Study 1 investigates consumer meanings of the term ethical and reveals that, contrary to philosophical scholars' exclusively consequentialist or nonconsequentialist positions, consumers' ethical judgments are a function of both these evaluation principles, illustrating that not anyone's scholarly definition of ethics alone is capable of capturing the content domain. The resulting conceptualisation identifies six key themes explicating the construct. Studies 2 and 3 were built upon these findings to operationalise CPE. Such operationalisation is an essential prerequisite for future explorations and theory development, given the absence of a suitable tool to capture and quantify the strength and direction of CPE. The key focus was on developing a valid and reliable multi-item measurement tool that is practical, parsimonious, and easy to administer. The scale's general applicability allows deployment in academic and business contexts and different research areas and doing thus facilitates the much-needed theory building in this new research area $[32,33]$.

A study examined political, corporate social responsibility with the intent to review theories and set new agendas. The study anchored on a survey and content analysis of 146 related academic articles from selected journals over a 14-year period of 2000 to 2013. Legitimacy theory, the resource-based view, and Habermasian political theory were reviewed within the political CSR literature. The survey showed that the political CSR field is primarily dominated by institutional theory and stakeholder theory. However, future theory development needs to go beyond these theories to address several CSR critical gaps. This review specifically points to several avenues for future political CSR research with regard to the 
individual level of analysis, domain integration, and political CSR in multinational enterprises. The paper, therefore, calls for a new theoryinformed and pluralist research agenda on political CSR in order to integrate different perspectives and re-examine the role of the state [34].

Another study that assessed the relationship between corporate social responsibility and financial performance aims to review alternative operationalization and measurement approaches for the CSR and CFP concepts that have been deployed in empirical literature concerned with the CSR-CFP relationship. Several findings emanate from the study.

First, CSR operationalization in empirical literature ranges from multidimensional to onedimensional. Second, CSR measurement approaches include reputation indices, content analyses, questionnaire-based surveys, and onedimensional measures, whereas CFP measurement approaches include accountingbased measures, market-based measures, and combined measures. Third, no CSR measurement approach is without drawbacks [8]. In addition to approach specific drawbacks, two problems inherent in most approaches are researcher subjectivity and selection bias that may influence the nature of the CSR-CFP relationship detected in the empirical literature. The study recommends that standardisation and disclosure would be not only beneficial for valid testing of the CSR - CFP relationship but also for many stakeholders when making their economic decisions. A study carried out a latent variable analysis of corporate social responsibility and firm value using Data from United States firms between 2002 and 2014. The study adopted a firm-fixed effects model to control for time-invariant unobservable firmspecific characteristics that may drive both CSR and firm value. Environmental, social, and corporate governance activities were measures of CSR. The study finds conflicting evidence of a direct relationship between each CSR proxy and firm value. However, joint positive significance were recorded when all CSR proxies are incorporated into a latent variable model. The study recommended that firm values can be enhanced by corporate managers through simultaneous engaging in environmental, social, and corporate governance activities because of their synergistic effect with firm value [35].

\section{Methodology}

The methodology for this research was both quantitative and qualitative approach. It includes the specific techniques or procedures adopted for gathering information for the study. It involved the collection, collation, analyses, and interpretation of data for the study of interest. This study is designed with the conscious aim to serve business managers by examining the effect of corporate reputation on the performance of corporate organizations with operations in West Africa. The design is multiple regression analysis based.

\section{Research Design}

The study adopted a survey research design incorporating both a quantitative approach and a survey strategy for interviews. In the current research context, perceptions of the individuals were sought in order to examine the effect of corporate reputation on the performance of corporate organizations: Evidence from West Africa.

The use of surveys enabled the researcher to obtain valid and reliable information through analyzing and understanding the data from the corporations. This is because the design is useful and most appropriate in measuring the degree of association between two or more variables. It is also useful in measuring the effect of independent variables on a dependent variable [36]. The dimension of the independent variable was Reputation (REP). The measure of the dependent variable is Corporate Performance (COP). These will be measured in an interval scale through the research questionnaire. The statistical tool to analyze the set variables is multiple regression. 


\section{Population}

The population for our study consists of selected listed multinational companies in Nigeria. The chosen companies include Cadbury Nig., Nestle Nig Plc., Unilever Nig. Glaxo Smith Kline, 7up Bottling, Guinness Nig. Plc., PZ Cussons, Nigeria Breweries, Dangote
Cement, Dangote Sugar, Flour Mills Nig. These were selected based on their multinational capacity, and as a listed company in the Nigerian Stock Exchange, they are required to practice corporate social responsibility. From the companies' database, there were a total of 30492 employees.

Table 1. Total Population

\begin{tabular}{|l|l|}
\hline Companies Names & No. of Targeted Employees \\
\hline Cadbury Nigeria Plc. & 536 \\
\hline Nestle Nigeria Plc. & 2226 \\
\hline Unilever Nigeria Plc. & 1010 \\
\hline GlaxoSmithKline Nig. Plc. & 125 \\
\hline 7up Bottling Company Plc. & 3452 \\
\hline Guinness Nigeria Plc. & 822 \\
\hline PZ Cussons & 1392 \\
\hline Nigeria Breweries & 3195 \\
\hline Dangote Cement & 13360 \\
\hline Dangote Sugar & 694 \\
\hline Flour Mills Nig. & 3680 \\
\hline Total & 30492 \\
\hline
\end{tabular}

Source: Companies’ Database

\section{Sampling Techniques}

The study sample was based on the population comprising of multinational companies in Nigeria. The sampling technique is a simple sampling method. In this technique, all the items of the population have equal chances of being selected in a sample. The selection of items could be done through either simple sampling, systematic sampling, stratified sampling, or cluster sampling [37]. A stratified sampling technique was adopted to select the multinational companies. While a simple sampling technique was used to select respondents.

The simple sampling major advantage over simple random sampling is that it is faster and less susceptible to sampling errors. In stratified sampling, the target population is divided into homogeneous sub-populations before a simple or systematic sampling is then used to further select items equally [38].

\section{Sample Size Determination}

To ensure that the sample size is truly reflective of the population, the Taro Yemen formula was used in this study. Since the larger the size of the population, the more precise the results, the investigation sample was drawn based on a 95the \% level of confidence. The Taro Yamene formula is given as:

$$
\mathrm{n}=\frac{\mathrm{N}}{1+N(e)^{2}}
$$

Where:

$$
\begin{aligned}
\mathrm{n}= & \text { Sample size } \\
\mathrm{N}= & \text { Population size } \\
\mathrm{e}= & \text { Margin of error }(5 \%) \\
& n=\frac{30492}{1+30492(0.05)^{2}} \\
= & \frac{30492}{1+30492(0.0025)} \\
= & \frac{30492}{1+76.23}
\end{aligned}
$$




$$
\begin{aligned}
& =\frac{30492}{77.23} \\
& =394.82
\end{aligned}
$$

$\mathrm{n}=395$, therefore the number of questionnaires administered is 395 .

\section{$=395$ approximately}

Table 2: Sample Number from Companies

\begin{tabular}{|l|l|l|l|}
\hline Companies Names (A) & $\begin{array}{l}\text { No. of Targeted } \\
\text { Employees }(B)\end{array}$ & $\begin{array}{l}\text { Percentage of } \\
\text { Total }(\mathbf{C})\end{array}$ & $\begin{array}{l}\text { Number from } \\
\text { Sample (C*395) }\end{array}$ \\
\hline Cadbury Nigeria Plc. & 536 & 0.018 & 7 \\
\hline Nestle Nigeria Plc. & 2226 & 0.073 & 29 \\
\hline Unilever Nigeria Plc. & 1010 & 0.033 & 13 \\
\hline GlaxoSmithKline Nig. Plc. & 125 & 0.004 & 2 \\
\hline 7up Bottling Company Plc. & 3452 & 0.113 & 45 \\
\hline Guinness Nigeria Plc. & 822 & 0.027 & 11 \\
\hline PZ Cussons & 1392 & 0.045 & 18 \\
\hline Nigeria Breweries & 3195 & 0.105 & 41 \\
\hline Dangote Cement & 13360 & 0.438 & 173 \\
\hline Dangote Sugar & 694 & 0.023 & 9 \\
\hline Flour Mills Nig. & 3680 & 0.121 & 47 \\
\hline Total & 30492 & 1.000 & 395 \\
\hline
\end{tabular}

Source: Authors' Computation

\section{Data Collection}

\section{Questionnaire}

Questionnaires were used to obtain the primary data required for this work, and these were administered by 10 persons trained by the researcher for the purpose of data collection in the field. Questionnaires are best suited for surveys [37]. Its selection was guided by the nature of data to be collected, the time available, and the study objectives.

Questionnaires have the advantage of upholding confidentiality, saving on time, reducing interviewer 's bias, wider coverage, and are easier to analyze [36]. The research adopted 5 Likert scale of Strongly Agreed (SA) $=5$, Agreed $(\mathrm{A})=4$, Undecided $(\mathrm{U})=3$, Disagreed $(\mathrm{D})=2$ and Strongly Disagreed (SD) $=1$ in rating the responses from the respondents. The respondents were required to read, understand, and tick an appropriate choice. The questionnaires were administered by the trained persons so as to obtain more information and also obtain clarity of information obtained from the respondents.

\section{Model Specification}

Our model for the study is anchored on previous studies with modifications. As mentioned in the previous section and in line with recent literature [34, 39]. Multiple regression using ANOVA was used as the research method for analyzing corporate reputation and its impact on the performance of corporate organizations. Therefore, the following equation is formulated for the study.

$$
C O P=f(R E P) \text {. }
$$

Expressing the functional notation in equation (1.0) in econometric form.

$$
\begin{aligned}
C O P=\beta_{0+} \beta_{1} & +R E P \\
& +\varepsilon_{1} \ldots
\end{aligned}
$$

Where:

COP $=$ Corporate Performance
REP $=$ Reputation
$\beta_{0}=$ Constant


$B_{1}=$ Coefficients

$\varepsilon_{\mathrm{i}} \quad=$ Error term

\section{Result and Discussion}

Response Rate: This chapter deals with the presentation, analysis and interpretation of the data obtained. The presentation of data was organized in accordance with the research questions and the hypotheses formulated for the study. Discussions of the findings were also made.

\section{Return Rate of Questionnaire}

Table 3. Return Rate of Questionnaire

\begin{tabular}{|l|l|l|l|l|l|}
\hline $\begin{array}{l}\text { Companies } \\
\text { Samples }\end{array}$ & Administered & $\begin{array}{l}\text { Correctly } \\
\text { Filled and } \\
\text { Returned }\end{array}$ & $\begin{array}{l}\text { Correctly } \\
\text { Filled and } \\
\text { Returned (\%) }\end{array}$ & $\begin{array}{l}\text { Incorrectly } \\
\text { Filled or Not } \\
\text { Returned }\end{array}$ & $\begin{array}{l}\text { Incorrectly } \\
\text { Filled or Not } \\
\text { Returned (\%) }\end{array}$ \\
\hline Cadbury Nig. & 7 & 7 & 1.8 & 0 & 0 \\
\hline Nestle Nig. & 29 & 28 & 7.1 & 1 & 0.25 \\
\hline Unilever Nig. & 13 & 12 & 3.0 & 1 & 0.25 \\
\hline GSK. Nig. & 2 & 2 & 0.5 & 0 & 0 \\
\hline 7up Bottling & 45 & 43 & 10.9 & 2 & 0.5 \\
\hline Guinness Nig. & 11 & 11 & 2.8 & 0 & 0 \\
\hline PZ Cussons & 18 & 17 & 4.3 & 1 & 0.25 \\
\hline Nig. Breweries & 41 & 40 & 10.1 & 1 & 0.25 \\
\hline Dangote Cement & 173 & 170 & 43.0 & 3 & 0.8 \\
\hline Dangote Sugar & 9 & 9 & 2.3 & 0 & 0 \\
\hline Flour Mills Nig. & 47 & 45 & 11.4 & 2 & 0.5 \\
\hline Total & $\mathbf{3 9 5}$ & $\mathbf{3 8 4}$ & $\mathbf{9 7 . 2}$ & $\mathbf{1 1}$ & $\mathbf{2 . 8}$ \\
\hline
\end{tabular}

Source: Field Survey, 2020

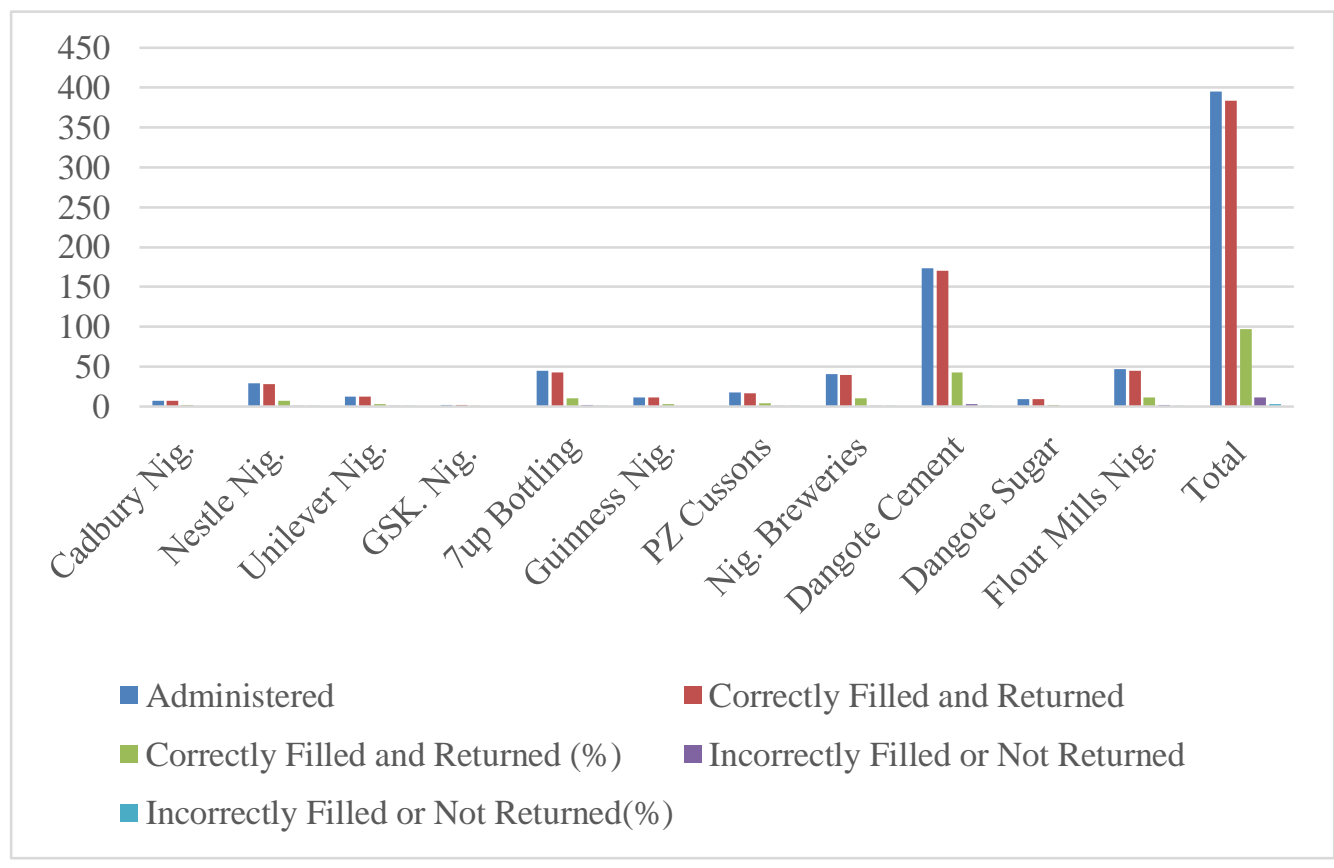

Figure 1. Analysis of Questionnaires Distributed to Companies Selected for this Study

Source: Field Survey, 2020 
The above table and chart sho that three hundred and ninety-five (395) copies of the questionnaire were administered to the respondents from each selected companies. Out of this number, three hundred and eighty-four (384) were correctly filled and returned, while eleven (11) copies were not correctly filled or not returned (see Table 3). This gives a response rate of $97.2 \%$. From these responses, data was organized, interested, and presented in this chapter.

\section{Background Information}

\section{Demographic Information}

Demographic results in table 4 revealed that $54.7 \%$ (210) were male and $45.3 \%$ (174) were female. It also revealed that most, $74.0 \%$ (284), were married, followed by $17.2 \%$ (66) which were single, and only $8.9 \%$ (34) respondents were divorced. The result also revealed that most $33.9 \%$ (130) of the respondents were aged between 36 - 45 years, followed closely by $29.9 \%$ (115) aged 46 years and above. $21.6 \%$
(83) were aged 26 - 35 years, and only $14.6 \%$ (56) were aged $16-25$ years.

In terms of their education qualification, $22.4 \%$ (86) of the respondents had their Senior Secondary Certificate Examination (SSCE), $8.6 \%$ (33), and 8.3\% (32) of the respondents had Ordinary National Diploma (OND) and Higher National Diploma (HND) respectively. 19\% (73) of the respondent had Master Certificate, 36.2\% (139) of the respondent had Master Certificate, and $5.5 \%$ (21) respondents had another certificate. Regarding their years in the corporation, $67.7 \%$ (260) of the respondents had stayed a decade and above, while $32.3 \%$ (124) were less than a decade in the corporation. Furthermore, $47.1 \%$ (181) of the respondents were low-level managers, 36.2\% (139 (were) middle-level manager, and $16.7 \%$ (64) were toplevel manager. This shows that men and women are almost equally involved in decision-making in the selected companies. It further revealed that the corporation had people of various ages and academic qualifications among the workforce with different years of experience.

Table 4. Demographic Information

\begin{tabular}{|l|l|l|}
\hline Variables & Frequency & Percentage \\
\hline Sex & 210 & 54.7 \\
\hline Male & 174 & 45.3 \\
\hline Female & $\mathbf{3 8 4}$ & $\mathbf{1 0 0}$ \\
\hline Total & 66 & 17.2 \\
\hline Marital Status & 284 & 74.0 \\
\hline Single & 34 & 8.9 \\
\hline Married & $\mathbf{3 8 4}$ & $\mathbf{1 0 0}$ \\
\hline Divorced & 56 & 14.6 \\
\hline Total & 83 & 21.6 \\
\hline Age & 130 & 33.9 \\
\hline $16-25$ Years & 115 & 29.9 \\
\hline 26-35 Years & $\mathbf{3 8 4}$ & $\mathbf{1 0 0}$ \\
\hline 36-45 Years & 124 & 32.3 \\
\hline 46 Years and above & 67.7 \\
\hline Total & 260 & \\
\hline Years in Corporation & \\
\hline Less than a decade & \multicolumn{2}{|l|}{} \\
\hline A decade and above &
\end{tabular}




\begin{tabular}{|l|l|l|}
\hline Total & $\mathbf{3 8 4}$ & $\mathbf{1 0 0}$ \\
\hline Job Level & 181 & 47.1 \\
\hline Low level manager & 139 & 36.2 \\
\hline Middle Level manager & 139 & 16.7 \\
\hline Top Level manager & 64 & $\mathbf{1 0 0}$ \\
\hline \multicolumn{2}{|l|}{ Total } & $\mathbf{3 8 4}$ \\
\hline \multicolumn{2}{|l|}{ Education Qualification } \\
\hline SSCE & 86 & 22.4 \\
\hline OND & 33 & 8.6 \\
\hline HND & 32 & 8.3 \\
\hline BSC/BA & 139 & 36.2 \\
\hline MSC/MBA & 73 & 19.0 \\
\hline Others & 21 & 5.5 \\
\hline Total & $\mathbf{3 8 4}$ & $\mathbf{1 0 0}$ \\
\hline
\end{tabular}

Source: Field Survey, 2020

\section{Specific Research Findings}

This section provides descriptive statistics, including frequencies, percentages, the mean and standard deviation for reputation and Corporate Performance. Therefore, descriptive statistics enable us to present the data in a more meaningful way, which allows a more straightforward interpretation of the data.

\section{Reputation (REP)}

Further, the reputation of the corporation was inquired from the respondents. From the study results, maintaining high-quality products has boosted the reputation of the corporation (mean $=4.4$ ), and the corporation considers various stakeholders when implementing social responsibility policies $($ mean $=3.51)$. The corporation has competent personnel dedicated to responding to complaints and brand-related issues (mean $=3.5$ ). However, the respondents expressed concern whether engaging the community through various socio-economic initiatives has been effective (mean $=2.78$ ). Also, there was doubt whether the internet and social media platforms have been adopted to promote the corporations' reputation (mean = 2.33) - responses on reputation show skewness of 0.79 and kurtosis of -0.50 . A similar study reports that corporate reputation is a critical resource and contributes mainly to the organization's performance or success. It can contribute to an organization's failure $[40, \&$ 41].

Table 5. Descriptive Statistics for Reputation (Frequencies, Percentages, means, and Standard Deviation)

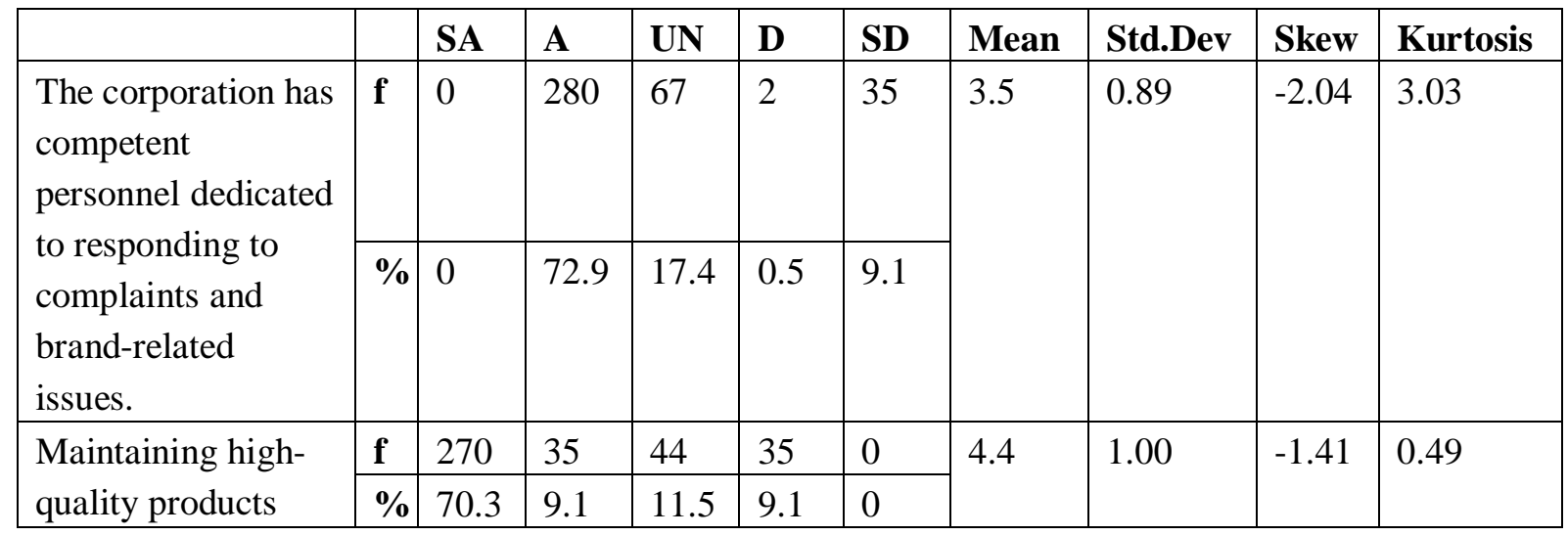




\begin{tabular}{|c|c|c|c|c|c|c|c|c|c|c|}
\hline $\begin{array}{l}\text { has boosted the } \\
\text { reputation of the } \\
\text { corporation. }\end{array}$ & & & & & & & & & & \\
\hline \multirow[b]{2}{*}{$\begin{array}{l}\text { The internet and } \\
\text { social media } \\
\text { platforms have } \\
\text { been adopted to } \\
\text { promote the } \\
\text { corporations' } \\
\text { reputation. }\end{array}$} & $\mathbf{f}$ & 33 & 36 & 1 & 271 & 43 & \multirow[t]{2}{*}{2.33} & \multirow[t]{2}{*}{1.07} & \multirow[t]{2}{*}{1.43} & \multirow[t]{2}{*}{1.12} \\
\hline & $\%$ & 8.6 & 9.4 & 0.3 & 70.6 & 11.2 & & & & \\
\hline \multirow[b]{2}{*}{$\begin{array}{l}\text { Engaging the } \\
\text { community through } \\
\text { various socio- } \\
\text { economic } \\
\text { initiatives has been } \\
\text { effective. }\end{array}$} & $\mathbf{f}$ & 68 & 33 & 67 & 182 & 34 & \multirow[t]{2}{*}{2.78} & \multirow[t]{2}{*}{1.25} & \multirow[t]{2}{*}{0.67} & \multirow[t]{2}{*}{-0.78} \\
\hline & $\%$ & 17.7 & 6.6 & 17.4 & 47.4 & 8.9 & & & & \\
\hline \multirow[b]{2}{*}{$\begin{array}{l}\text { The corporation } \\
\text { considers various } \\
\text { stakeholders when } \\
\text { implementing } \\
\text { social responsibility } \\
\text { policies. }\end{array}$} & $\mathbf{f}$ & 138 & 104 & 33 & 34 & 75 & \multirow[t]{2}{*}{3.51} & \multirow[t]{2}{*}{1.52} & \multirow[t]{2}{*}{-0.62} & \multirow[t]{2}{*}{-1.13} \\
\hline & $\%$ & 35.9 & 27.1 & 8.6 & 8.9 & 19.5 & & & & \\
\hline \multicolumn{7}{|l|}{ Reputation } & 3.25 & 0.45 & 0.79 & -0.503 \\
\hline
\end{tabular}

Source: Field Survey, 2020

\section{Multiple Regression Result}

The regression result from table 6 shows that the study multiple regression model had a coefficient of determination $\left(\mathrm{R}^{2}\right)$ of 0.527 . This means that community development \& philanthropy, reputation, internationalization, environmental sensitivity, employee diversity, and leadership ethics explain a $52.7 \%$ variation of corporate performance. Furthermore, the reveals that the F-value of 70.029 with a p-value of 0.00 significant at $5 \%$ indicates that the overall regression model is significant; hence, the joint contribution of the independent variables was significant in predicting the corporate performance.

Table 6. Multiple Regression Results

\begin{tabular}{|l|l|l|l|l|l|}
\hline \multirow{2}{*}{ Model } & Unstandardized Coefficients & Standardized Coefficients & t & Sig. \\
\cline { 2 - 5 } & B & Std. Error & Beta & & \\
\hline Constant) & -2.641 & .494 & & -5.350 & .000 \\
\hline Reputation & .227 & .108 & .089 & 2.105 & .036 \\
\hline R Square 0.527 & & & \\
\hline Adjusted R Square 0.520 & \\
\hline F 70.029 \\
\hline Sig. 0.000 \\
\hline
\end{tabular}

Source: SPSS 20.0 


\section{Test of Hypothesis}

To test for hypotheses, we first state the null and alternative forms to create a clear understanding of the tentative statements.

\section{Decision Rule}

The decision rule is to reject the null hypothesis and accept the alternative if the sig. Value of the variables under study is lower than 0.05 level of significance.

$\mathrm{Ho}_{1}$ : Firm's reputation does not significantly affect the performance of corporate organizations in developing countries.

$\mathrm{H}_{\mathrm{A} 1}$ : Firm's reputation significantly affects the performance of corporate organizations in developing countries.

Table 7. Standardized Coefficient

\begin{tabular}{|l|l|l|l|}
\hline Variable & Standardized Coefficient (Beta) & t-Stat & Sig. \\
\hline Reputation & 0.089 & 2.105 & 0.036 \\
\hline
\end{tabular}

Source: Extracted from Table

The second hypothesis $\left(\mathrm{Ho}_{1}\right)$ of the study stipulates that firm's reputation do not significantly affect the performance of corporate organizations in developing countries. Study result findings from table 7 rejected the hypothesis as evidenced by $\beta_{2}=0.089, \rho<0.05$, implying that firm's reputation significantly affects the performance of corporate organizations in developing countries. We, therefore, reject the null hypothesis that a firm's reputation do not significantly affect the performance of corporate organizations in developing countries.

This shows that the higher a firm's reputation, the higher the performance. These findings are consistent with another study which posits that corporate reputation as a logical outcome of the quality of corporate governance operated in an organization [40].

\section{Summary of Findings}

The study investigated the effect of corporate reputation on the performance of corporate organizations in developing countries using evidence from West Africa. The relevance of corporate reputation in enhancing the performance of corporate organizations have ignited concerns of scholars following the world globalization with related challenges. The study adopted various tests to establish the association between the variables under study. The effect of
Reputation (REP) on the performance of corporate organizations was tested and the study established from the regression that there is a positive effect of Reputation (REP) on performance of corporate organizations. This is evidenced by the coefficient value of 0.089 . Statistically, the Sig. Value of 0.036 is lower than the acceptable significance value of 0.05 . Following the empirical result, Reputation (REP) is found to have a positive and significant effect on the performance of corporate organizations.

The powerful effect is in line with a study showing that funds meant to be invested in the CSR in the various companies are not sufficient. Furthermore, another study posits that the key to good results lies in establishing a strong informative system that, to the extent possible, links specific CSR expenditure decisions so as to ensure the usage of the allocated fund as transparently as possible [43]. However, another study noted that the efficiency of corporations' expenditure for building intangible assets like reputation and brand varies across nations [44]. The finding reveals that as in reputation, financing has increased over the years with its growing relevance adequately.

\section{Conclusion}

In conclusion, the heterogeneity that exists among corporate reputation variable as it relates 
to the performance of corporate organizations call for re-engineering in order to explore the potential growth virtues embedded in corporate reputation that are yet to be adopted by organizations. The positive coefficients of reputation, in relation to the performance of corporate organizations in developing countries, is a further indicator that the organizations can become better through the long-term focus strategy on these practices to accelerate performance. The study also reveals that the many environmental challenges faced by multinationals emanating from corporate social responsibilities can be well addressed through enhanced strategic policy implementation.

\section{Recommendation}

Reputation (REP) from our study has a positive coefficient is a significant effect. This means that reputation building by corporations contributes to the performance of the corporations meaningfully. We advocate for an increase in the level of attention given to the reputation of the corporation in carrying out their numerous activities.

\section{Conflict of Interest}

I hereby certify that, to the best of my knowledge: No financial support or benefits have been received by me, by any member of my immediate family, or any individual or entity

\section{References}

[1] Rieschick, G. (2017). Corporate social responsibility and corporate financial performance in food, and beverage industry (Doctoral dissertation). Retrieved from Walden Dissertations and Doctoral Studies.

https://scholarworks.waldenu.edu/dissertations/4677

[2] Akhalumeh, P., Odion, O., \&Ohiokha, F., (2016). Corporate Social Responsibility and Corporate Financial Performance: The Nigerian Experience. with whom or with which I have a significant relationship from any commercial source which is related directly or indirectly to the work which is reported on in the article. I declare that I have no conflict of interest.

\section{Acknowledgement}

I owe an enormous debt to different people for helping me create this doctoral thesis.

First, my deepest gratitude goes to my Guide/Supervisor, Professor James C. Ihemeje, Professor of Finance at the Michael Okpara University of Agriculture Umudike, for his guidance, scholarly support, and dedication of time, without which this thesis would not have become a reality.

Secondly, I acknowledge my CoGuide/Supervisor, Dr.N.S. Shanthi, for her scholarly support and commitment of time throughout this process. I am also thankful to Dr. Janani S.B., my Research Coordinator, Dr. Kulothungan, my student mentor, and Dr. Ogochukwu E.S. Nebo, my alumni mentor, for inspiring me to complete this doctoral thesis and for providing me with unlimited academic support.

The fine team of professionals at the School of Research, Texila American University, has also been instrumental to the success of my program and for this thesis. I will admire their dedication throughout my life.

International Journal of Accounting Research, 2, 113. doi: 10.12816/0027131.

[3] Yu-Shu, P., Chyi-Lin, H., \&Altan-Uya, D., (2015). Corporate Social Responsibility and Corporate Financial Performance: The Intervening Effect of Social Capital. Journal of Advanced Management Science, 3(4), 276-283. Doi: 10.12720/joams.3.4.276-283.

[4] Tilakasiri, K.K. (2012). Corporate social responsibility and company performance: Evidence from Sri Lanka (Doctoral dissertation). Retrieved from VU Research Repository. 
http://vuir.vu.edu.au/21488/1/Korathotage_Kamal_T ilakasiri.pdf.

[5] Babalola, A. (2012). The Impact of Corporate Social Responsibility on Firm's Profitability in Nigeria. European Journal of Economics, Finance and Administrative Sciences, 45, 39-50. Retrieved from

https://www.kau.edu.sa/Files/0060841/Subjects/imp act\%20on\%20profitiability.pdf.

[6] Jamali D., \&Sidani Y. (2012). Introduction: CSR in the Middle East: Fresh Perspectives. In: Jamali D., Sidani Y. (eds) CSR in the Middle East. (pp. 1-10). doi.org/10.1057/9781137266200_1.

[7] Nguyen, H.T., Le, D.M.D., Ho, T.T.M., \& Nguyen, P.M., (2020). Enhancing Sustainability in the Contemporary Model of CSR: A Case of Fast Fashion Industry in Developing Countries. Social Responsibility Journal, 17(4), 578-591. https://doi.org/10.1108/SRJ-03-2019-0108.

[8] Galant, A., \& Cadez, S. (2017). Corporate Social Responsibility and Financial Performance Relationship: A Review of Measurement Approaches. Economic ResearchEkonomskaIstraživanja, 30(1), 676-693. doi: 10.1080/1331677X.2017.1313122.

[9] Friedman, M. (1970). Capitalism and Freedom: Fortieth Anniversary Edition.

[10]Carroll, A., (1979). A Three-Dimensional Conceptual Model of Corporate Performance. Academy of Management Review, 4(4): 479-505.

[11]Baucus, M., \& Baucus, D. (1997). Paying the Piper: An Empirical Examination of Longer-Term Financial Consequences of Illegal Corporate Behavior. The Academy of Management Journal, 40, 129-151. doi: 10.2307/257023.

[12]Helm, S. (2007). One reputation or many? Comparing stakeholders' perception of corporate reputation, Corporate Communications: An International Journal, 12(3), 238-254.

[13] Sarstedt, M., Ringle, C. M., Schloderer, M. P., and Schwaiger, M., (2008). Accounting for Unobserved Heterogeneity in the Analysis of Antecedents and Consequences of Corporate Reputation: An Application of FIMIX-PLS, Proceedings of the $37^{\text {th }}$ Annual Conference of the
European Marketing Academy, Brighton, England, 27-30 May 2008, EMAC.

[14] Weiss, A. M., Anderson, E. and MacInnis, D. J. (1999). Reputation Management as A Motivation for Sales Structure Decisions, Journal of Marketing, 63(4).74-89.

[15]Hall, R., (1993). A Framework Linking Intangible Resources and Capabilities to Sustainable Competitive Advantage. Strategic Management Journal, 14, 607-618.

[16]Barney, J., (1991). Firm Resources and Sustainable Competitive Advantage. Journal of Management, 17, 99-120.

[17]Roberts, P.W., and Dowling, G.R., (2002). Corporate Reputation and Sustained Superior Financial Performance. Strategic Management Journal, $\quad 23, \quad$ 1077-1093. https://doi.org/10.1002/smj.274.

[18]Eberl, M., Schwaiger, M, (2005). Corporate Reputation: Disentangling the Effects on Financial Performance, European Journal of Marketing, 39(7/8), 834-54.

[19]Rose, C., \& Thomsen, S., (2004). The Impact of Corporate Reputation on Performance: Some Danish Evidence. European Management Journal, 22(2), 201-210.

[20] Inglis, R. Morley, C., Sammut, P., (2006). Corporate Reputation and Organisational Performance: An Australian Study. Managerial Auditing Journal, 21(9) 934-947.

[21]Fombrun, C., 1996, Reputation: Realizing Value from the Corporate Image, (Harvard Business School Press, Boston, MA).

[22] Fombrun, C., Gardberg, N., \& Sever, J., (2000). The reputation quotient SM: A Multi-stakeholders Measure of Corporate Reputation. The Journal of Brand Management, 7, 241-255.

[23] Brammer, S., \& Pavelin, S., (2004). Building a Good Reputation. European Management Journal, 22, 704-713. 10.1016/j.emj.2004.09.033.

[24] Wood D., (1991). Corporate Social Performance Revisited. The Academy of Management Review, 16(4), 691-717. 
[25] Moir L., (2001). What Do We Mean by Corporate Social Responsibility? Corporate Governance, 1(2), 16-22.

[26] Campbell D., Craven B., \& Shrives P., (2003). Voluntary Social Reporting in Three FTSE Sectors:

A Comment on Perception and Legitimacy. Accounting, Auditing and Accountability Journal, 16(4), 558-581.

[27] Gray, R., Kouhy, R. \& Lavers, S., (1995). Corporate Social and Environmental Reporting: A Review of the Literature and a Longitudinal Study of UK Disclosure. Accounting, Auditing \& Accountability Journal, 8(2), 47-77. https://doi.org/10.1108/09513579510146996.

[28] Dowling, J., \& Pfeffer, J., (1975). Organizational Legitimacy: Social Values and Organizational Behavior. Pacific Sociological Review, 18(1), 122 136. https://doi.org/10.2307/1388226.

[29]Deegan, C., (2002). Introduction: The Legitimising Effect of Social and Environmental Disclosures - A Theoretical Foundation. Accounting, Auditing \& Accountability Journal, 15(3), 282-311. https://doi.org/10.1108/09513570210435852.

[30]Deegan, C., Rankin, M., \& Voght, P., (2000). Firms' Disclosure Reactions to Major Social Incidents: Australian Evidence. Accounting Forum, 24(1), 101-130.

[31]Cormier, D., \& Gordon, I.M., (2001). An Examination of Social and Environmental Reporting Strategies. Accounting, Auditing \& Accountability Journal, $\quad$ 14(5), 587-617. https://doi.org/10.1108/EUM0000000006264.

[32]Pfeffer, J., \& Salancik, G., 1978, The external control of organizations: A resource dependence perspective. (Harper \& Row, New York).

[33]Brunk, K., (2012). Unethical company and Brand Perceptions: Conceptualizing and Operationalizing Consumer Meanings. Journal of Business $\quad$ Ethics, $111(4), \quad 551-565$. doi:10.1007/s10551-012-1339-x.

[34]Frynas, J. G., \& Stephens, S., (2015). Political Corporate Social Responsibility: Reviewing Theories and Setting New Agendas. International Journal of Management Reviews, 17(4), 483-509.
[35] Jitmaneeroj, B., (2018). A Latent Variable Analysis of Corporate Social Responsibility and Firm Value. Managerial Finance, Vol. 44(4), 478-494. https://doi.org/10.1108/MF-08-2017-0303.

[36] Tang, Q., \& Zhang, C., (2013). Data Processing System (DPS) Software with Experimental Design, Statistical Analysis, and Data Mining Developed for Use in Entomological Research. Insect Science, 20, 254-260. doi:10.1111/j.1744-7917.2012. 01519.x.

[37] Yusoff, H., Abdul Jamal, A.D., \& Darus, F., (2016). Corporate Governance and Corporate Social Responsibility Disclosures: An Emphasis on the CSR Key Dimensions. Journal of Accounting and Auditing: Research \& Practice, 1-14.

[38]Aykol, B., \& Leonidou, L. C., (2014). Researching the Green Practices of Smaller Service Firms: A Theoretical, Methodological, and Empirical Assessment. Journal of Small Business Management, 53, 192-209. doi:10.1111/jsbm. 12118.

[39] Mellahi, K., Frynas, J. G., Sun, P., \& Siegel, D., (2015). A Review of the Nonmarket Strategy Literature toward a Multi-Theoretical Integration. Journal of Management, 42(1), 143 -173.

[40] Aniuga, C. \& Okolo, A. N. (2015) The Impact of Corporate Reputation on Company's Performance. Communication Panorama African and Global Perspectives 1(1), 1 - 15.

[41]Honggui, G. L., Zhongwei, W. C., \&Guoxin, X. M., (2016). Corporate Reputation and Performance: A Legitimacy Perspective. Entrepreneurial Business and Economic Review, 4(3), 181 - 193. DOI: 10.15678/EBER.2016.040313.

[42] Kiessling, T., Isaksson, L., \& Yasar, B., (2015). Market Orientation and CSR: Performance Implications. Journal of Business Ethics, 137. doi: 10.1007/s10551-015-2555-y.

[43] Saadaoui, K., \&Soobaroyen, T., (2018). An Analysis of the Methodologies Adopted by CSR Rating Agencies. Sustainability Accounting, Management and Policy Journal, 9(1), 43-62. https://doi.org/10.1108/SAMPJ-06-2016-0031.

[44]Nelson, G., \& Evans, S. D., (2014). Critical Community Psychology and Qualitative Research: A Conversation. Qualitative Inquiry, 20, 158-166. doi:10.1177/1077800413510873. 